\title{
HULCARDIA
}

A Journal of Agricultural Science Published by the California Agricultural Experiment Station

\section{HERBICIDAL PROPERTIES \\ OF BENZENE AND CERTAIN METHYL DERIVATIVES}

H. B. CURRIER 
This paper reports some recent studies on the toxicity of benzene and several methyl derivatives for three plant species. Toxicity in both vapor and spray experiments increased in the order benzene, toluene, xylene, trimethylbenzenes; plant resistance in the order tomato, barley, carrot.

The physical basis of the acute toxic action of these hydrocarbons is indicated by the narrow concentration range of toxicity, change in activity with different diluents, and correIation of toxicity with water solubility, water-oil partition coefficients, and boiling points. Benzenes are good fat solvents: the mechanism of acute toxicity probably involves disorganization of the outer plasma membrane of the cell, due to solvent action on the lipoid constituents. Partition phenomena determine concentration of hydrocarbon at point of action.

Carrots showed relative resistance in all treatments. Basis of selectivity may lie in the character of the cell wall or of the outer plasma membrane. 


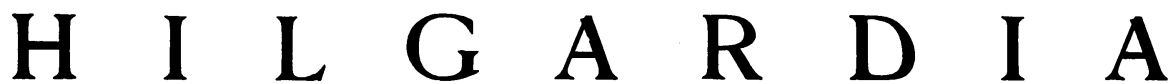

A Journal of Agricultural Science Published by

the California Agricultural Experiment Station

VOL. 20

FEBRUARY, 1951

No. 19

\section{HERBICIDAL PROPERTIES OF BENZENE AND CERTAIN METHYL DERIVATIVES ${ }^{1}$ \\ H. B. CURRIER ${ }^{2}$}

A GREAT MANY HERBICIDES in current use are aromatic compounds possessing a benzene ring structure. This applies both to a large number of contact poisons such as pentachlorophenol, to those of the hormone type of which 2,4-D is the best known example, and to various petroleum fractions used as weed oils. In view of this wide application of ring compounds, it was considered to be of interest to study the effects of benzene itself, and in so doing to prepare a basis for subsequent investigations of benzene derivatives. This paper presents the results of the study undertaken. Included here are reports on the comparative behavior of several methyl derivatives.

\section{EXPERIMENTAL PROCEDURE}

In order to treat plants with known and constant amounts of hydrocarbon vapors under standard conditions, a gas chamber was employed. Air at constant pressure was passed through a small vaporizing chamber containing the solvent, and the gas mixture led into the top of a bell jar containing the plants. Temperature of the plants was held at $25^{\circ} \mathrm{C}$; that of the hydrocarbon was varied as a means of changing the concentration. Air flow, standardized with a wet-test meter and regulated by a flowmeter, amounted to 11.5 liters per minute, and by measuring the amount of solvent evaporated per unit time the concentration of vapor in the air could be calculated.

Four different compounds were employed: benzene, toluene, xylene, and trimethylbenzenes. The first three were C.P. products, although the xylene, rated as C.P., was a mixture of isomers, but presumed to be the meta compound for the most part. The trimethylbenzenes is a product of technical grade $^{3}$ which probably contains all of the isomers and perhaps slight amounts of other materials as well. A few comparative tests were carried out using each of the three xylene isomers, and the symmetrical trimethylbenzene, mesitylene.

${ }^{1}$ Manuscript submitted for publication August 25, 1950.

${ }^{2}$ Assistant Professor of Botany and Assistant Botanist in the Experiment Station, Davis.

${ }^{3}$ Eastman No. T2549. 
Tomato, barley, and carrot were selected as test plants because of their known variability in degree of susceptibility to the hydrocarbons in question. They were grown in flat cans by standardized methods, 12 barley, three tomato, and 20 carrot plants per can. Tomatoes and carrots were treated 32 days after planting, barley 14 days after. The can technique, used extensively in greenhouse testing, yields a high degree of precision when pure seed, soil, watering, and other factors are kept constant.

Plants were treated in the gas chamber for $1 / 4,1 / 2$, one and two hours. In some of the barley tests $1 / 8$ hour and four hours were employed additionally where needed. The kind and extent of injury were recorded immediately after treatment and at regular intervals thereafter. Photographs were taken 24 hours after removal from the gas chamber.

Other plants were sprayed with each kind of hydrocarbon in a series consisting of a control can, $2 \mathrm{ml}, 5 \mathrm{ml}, 10 \mathrm{ml}$, and $20 \mathrm{ml}$. A special atomizer, constant air pressure, and a motor driven turntable aided in standardizing the treatment. After 57 days (from spraying) the fresh weights and heights of the tops were determined, and used to estimate relative rates of growth.

\section{RESULTS \\ Symptoms of Injury}

All four compounds entered the plants rapidly. The first noticeable symptom was a darkening of the tips of the youngest leaves, due presumably to a leakage of sap into the intercellular spaces. The darkening then spread to older leaves; there was a loss of turgor, with drooping of stems and leaves. Upon removal from the gas chamber, the plants exhibited strong odors similar to macerated tissues. In bright sunlight chlorophyll was destroyed, sometimes resulting in complete bleaching of the dead portions.

The rapidity with which plants respond to vapor treatment is shown in fig. 1 .

\section{Relative Toxicity of Hydrocarbons}

Toxicity in both vapor and spray treatments increased in the order benzene, toluene, xylene, trimethylbenzene (TMB), thus confirming the conclusions of Crafts and Reiber (1948), ${ }^{4}$ Havis (1950), and Leonard and Harris (1950), from spray data. This was more apparent in the spray than in the vapor tests, but since vapor pressure decreases in this same order, it was felt that evaporation losses in spraying could possibly result in an incorrect judgement of absolute toxicity. In the vapor treatments, toluene at a concentration of $1.3 \times$ $10^{-4} \mathrm{M}$ in air caused the same extent of injury to barley as benzene at $3.2 \times 10^{-4}$ $\mathrm{M}$; xylene at $0.46 \times 10^{-4} \mathrm{M}$ was very nearly as toxic ; and TMB at $0.12 \times 10^{-4} \mathrm{M}$, with a concentration $1 / 2$ t th that of benzene, was fully half as toxic. A somewhat similar result obtained with tomatoes, but not for carrots, where it seemed that the series reversed in the vapor treatments. However, this may have been due to the greater resistance of carrots, their greater tolerance of low concentrations of vapor, and the "concentration effect" described below (page 397 ). For the sprayed carrots toxicity increased in the order benzene, toluene, xylene, TMB. (Fig. 2.)

In one series of tests the concentration of vapor in the air stream was con-

${ }^{4}$ See "Literature Cited" for citations, referred to in the text by author and date. 
trolled at $2 \times 10^{-4} \mathrm{M}$ for each hydrocarbon. This clearly demonstrated that toxicity increased as methyl groups are added on to the molecule.

No significant difference was noted in the toxicity of the three pure xylene isomers, but all were slightly less toxic than the mixed xylenes. Mesitylene was much less toxic than the TMB mixture, being only a little more active than xylene.

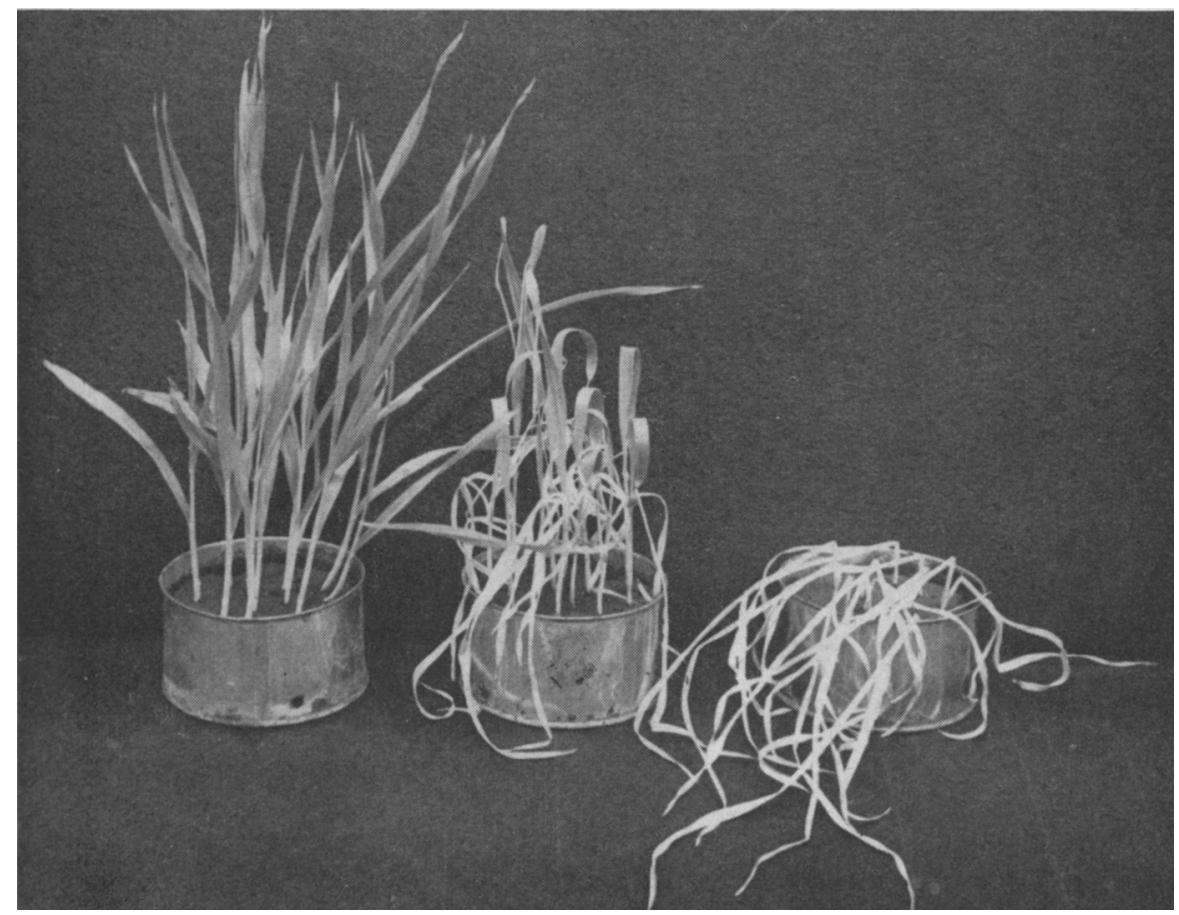

Fig. 1. Effect of benzene vapor on barley. Concentration $6.4 \times 10^{-4} \mathrm{M}$ per liter of air. Left to right: control, $15 \mathrm{~min} ., 30 \mathrm{~min}$. Photo 24 hours later.

\section{Relative Susceptibility of the Three Plant Species}

Under the conditions of these tests, tomato was most injured by the four hydrocarbons, carrot the least, barley was intermediate. Responses by the different plants to benzene spray are indicated by fig. 3, while fig. 4 shows results of toluene vapor treatment. The carrots and tomatoes in fig. 5 had the same treatment with xylene vapor.

\section{Effect of Varying the Concentration}

Several different concentrations of the four solvents in air were employed in the tests on barley. The toxicity appears to vary markedly within narrow limits. By lowering the concentration of benzene from 0.00032 to $0.00022 \mathrm{M}$ (about a third) the plants showed only $25 \%$ injury at the end of four hours exposure. All of these plants treated with the lesser concentration recovered completely; those given $0.00032 \mathrm{M}$ for one and two hours were dead soon 

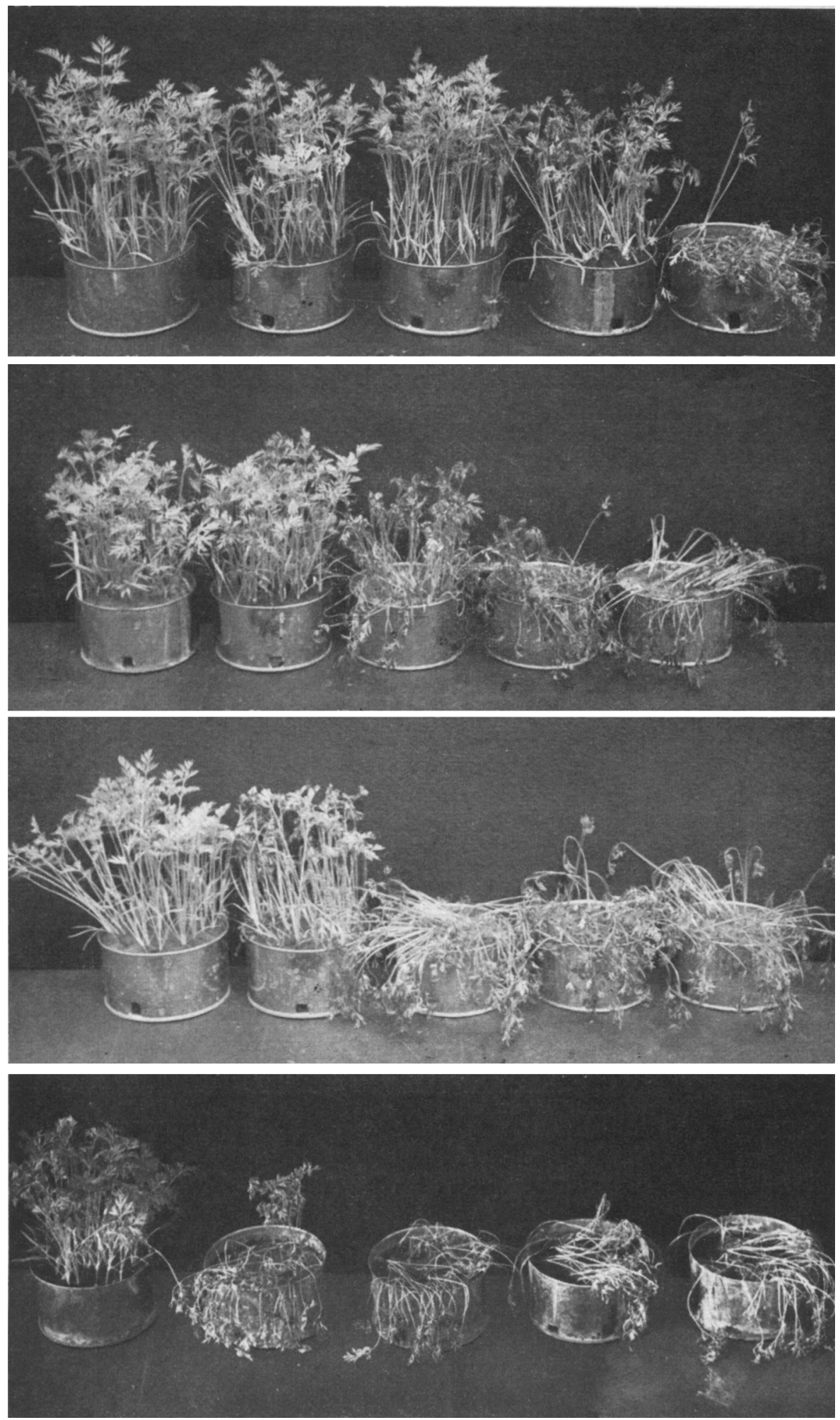

Fig. 2. Results of spray treatment of carrots where different amounts of hydrocarbons were applied. Top to bottom: benzene, toluene, xylene, trimethylbenzenes. Left to right: control, $2 \mathrm{ml}, 5 \mathrm{ml}, 10 \mathrm{ml}$. Photo 24 hours later. 


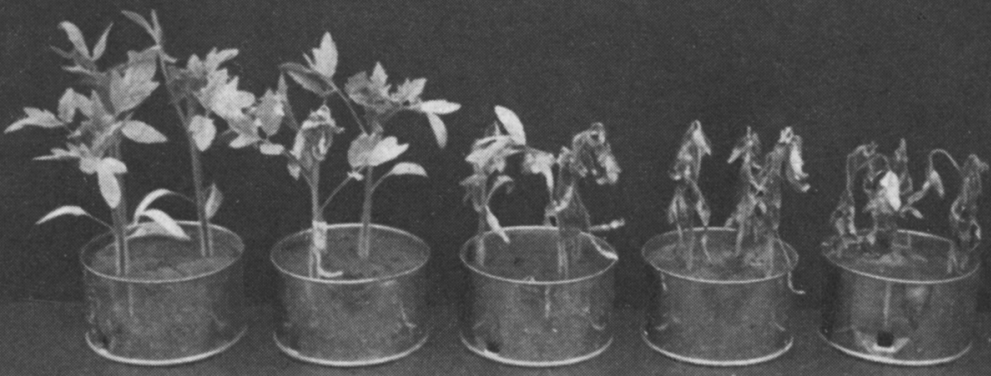

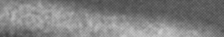
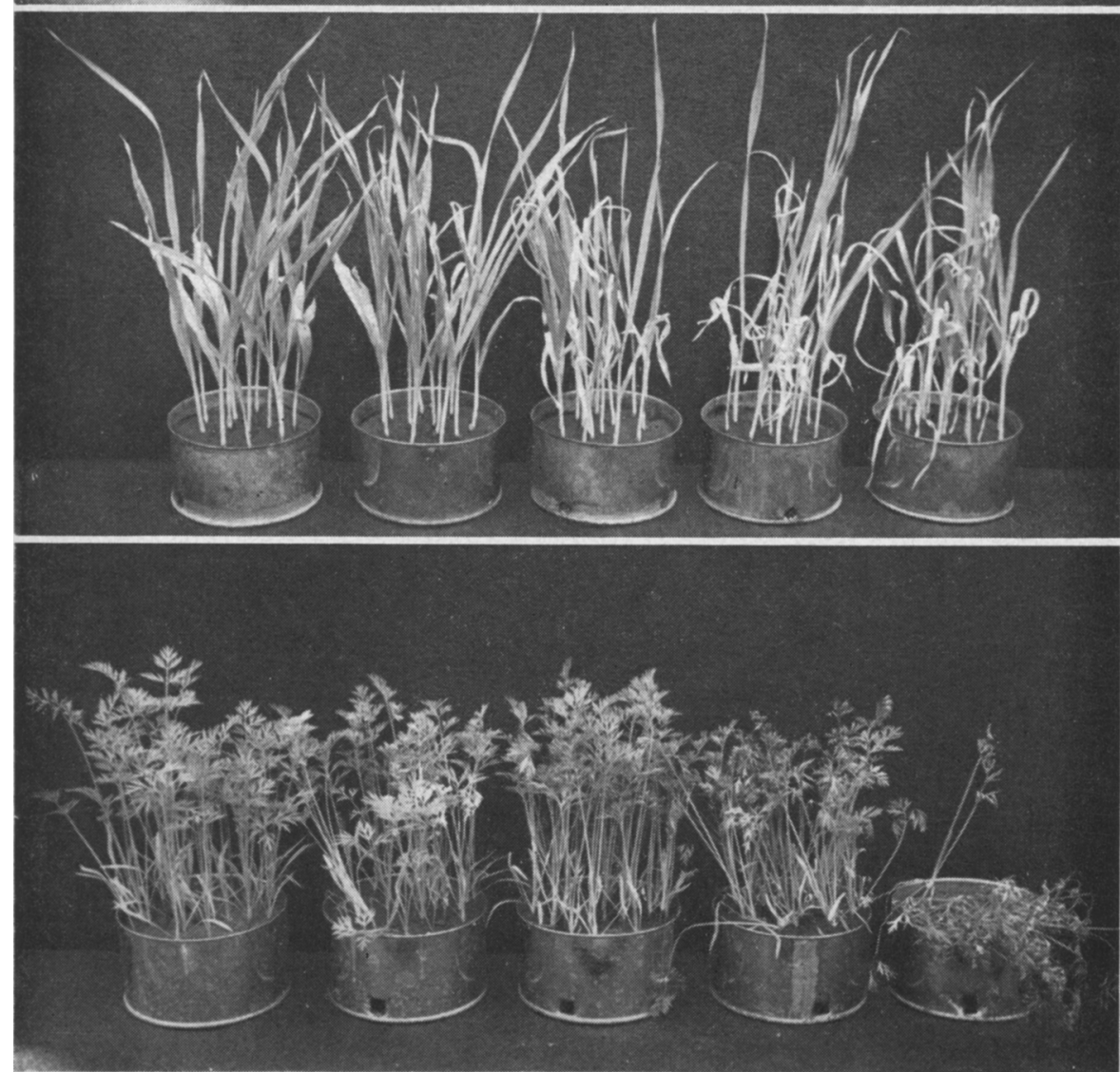

Fig. 3. Response by tomato, barley, and carrot to benzene spray. Left to right : control, $2 \mathrm{ml}, 5 \mathrm{ml}, 10 \mathrm{ml}, 20 \mathrm{ml}$. Photo 24 hours later. 

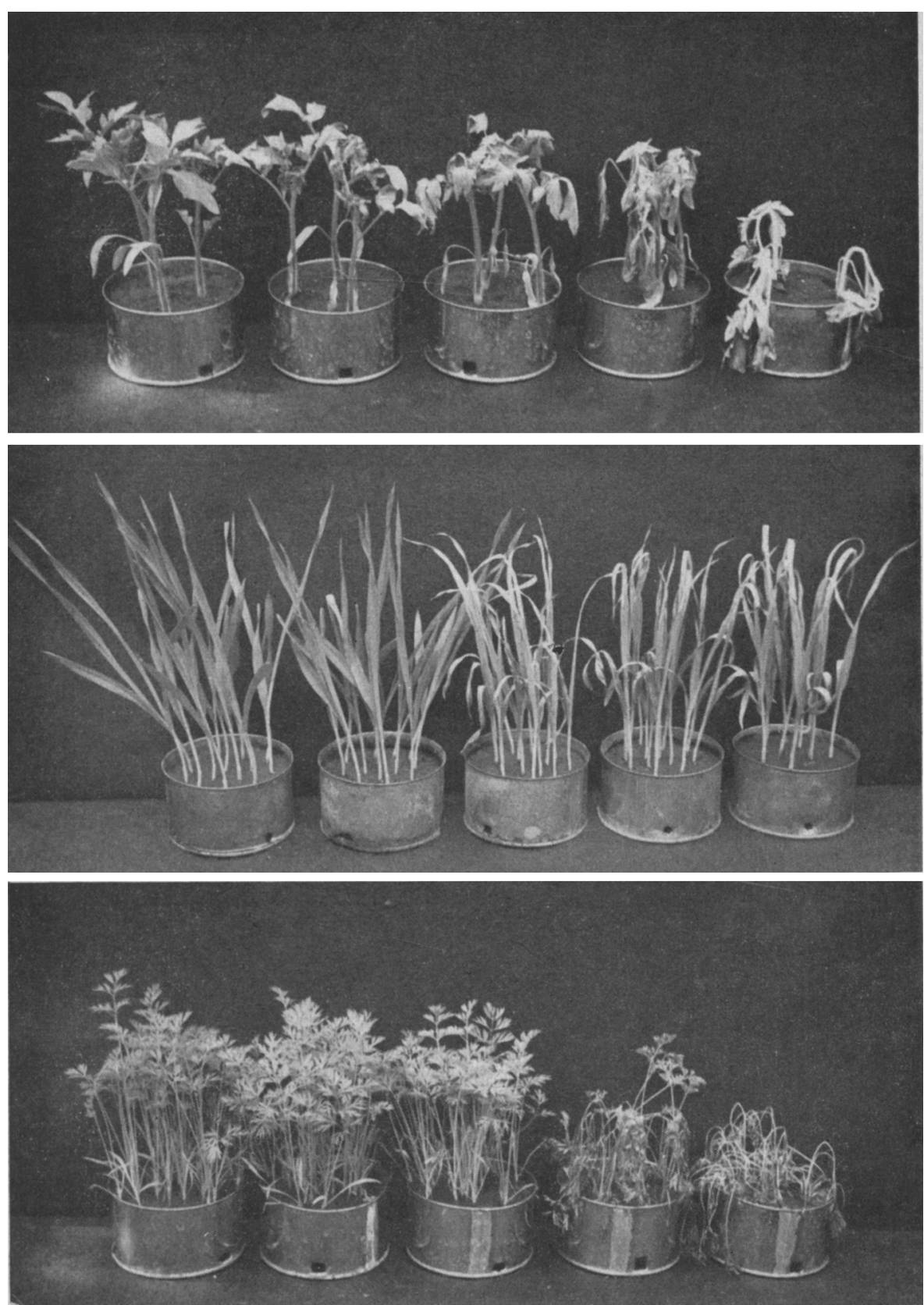

Fig. 4. Effect of toluene vapor at a concentration of $1.3 \times 10^{-4} \mathrm{M}$ per liter of air on tomato, barley, and carrot. Left to right: control, $1 / 4 \mathrm{hr}$., $1 / 2 \mathrm{hr}$., $1 \mathrm{hr}$., $2 \mathrm{hrs}$. Photo 24 hours later. 


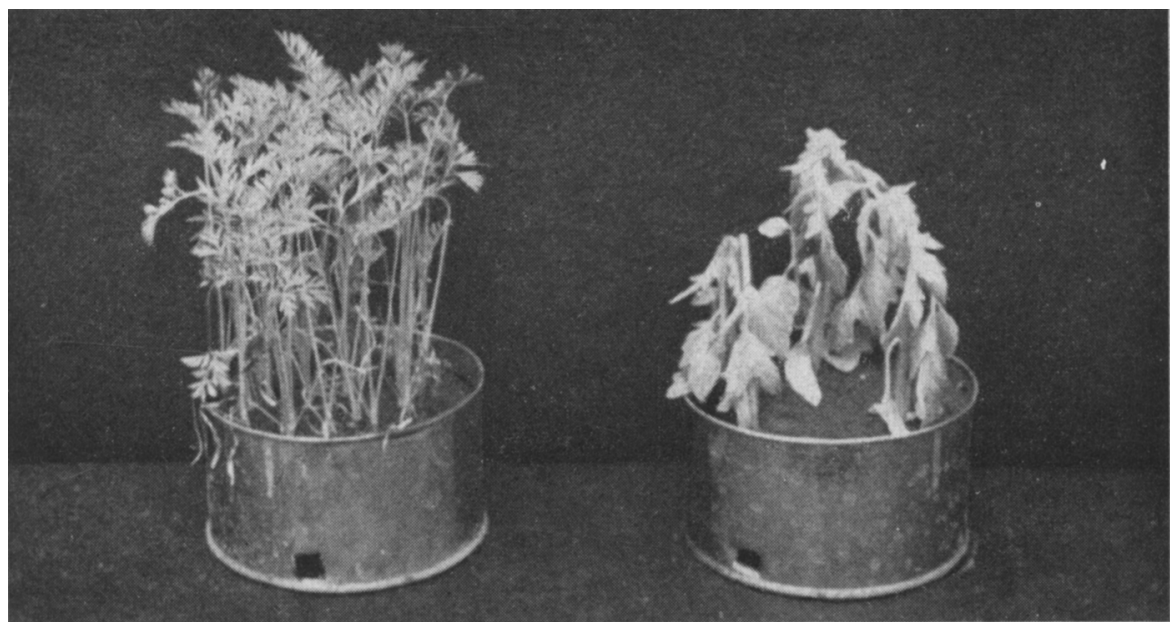

Fig. 5. Carrots and tomatoes treated with xylene vapor at a concentration of $0.46 \times 10^{-4} \mathrm{M}$ per liter of air for 2 hours. Carrots show no effect; the tomatoes are badly injured. Photo 24 hours later.

after. These same results were produced by toluene where the concentration was halved, $1.3 \times 10^{-4}$ to $0.69 \times 10^{-4} \mathrm{M}$. When the concentrations of xylene and trimethylbenzene were halved, there was almost no effect until four hours when injury began to appear. The response by barley to toluene vapor at varying concentrations is shown in fig. 6 .

On the other hand, increasing the concentration seemed only to increase the toxic response proportionately.

It would seem that the acute toxicity of these hydrocarbons is dependent on a certain level of concentration, and that low amounts can be tolerated for several hours with no permanent injurious effects. It is surprising that the concentration range is so narrow.

Complete data for the three plant species under vapor treatment with the four substances are given in tables 1 and 2 .

\section{Spraying vs. Vapor Treatment}

While spraying tests are of the greatest practical value, it is recognized that they do not always indicate absolute toxicity. Not only must evaporation rates from leaf surfaces be considered, but also the fact that the more volatile the substance the greater amount lost between the spray nozzle and the plant. Decrease of vapor pressure in the order benzene, toluene, xylene, TMB explains why a greater difference in toxicity of the four hydrocarbons was apparent in the spray than in the vapor treatments. Table 3 presents the spray data.

\section{Effect on Yield}

Eight weeks after treatment the aerial portions of the plants were cut off at the soil line and their fresh weights determined. The weight data show a general correlation with estimated per cent injury for both the vapor and 

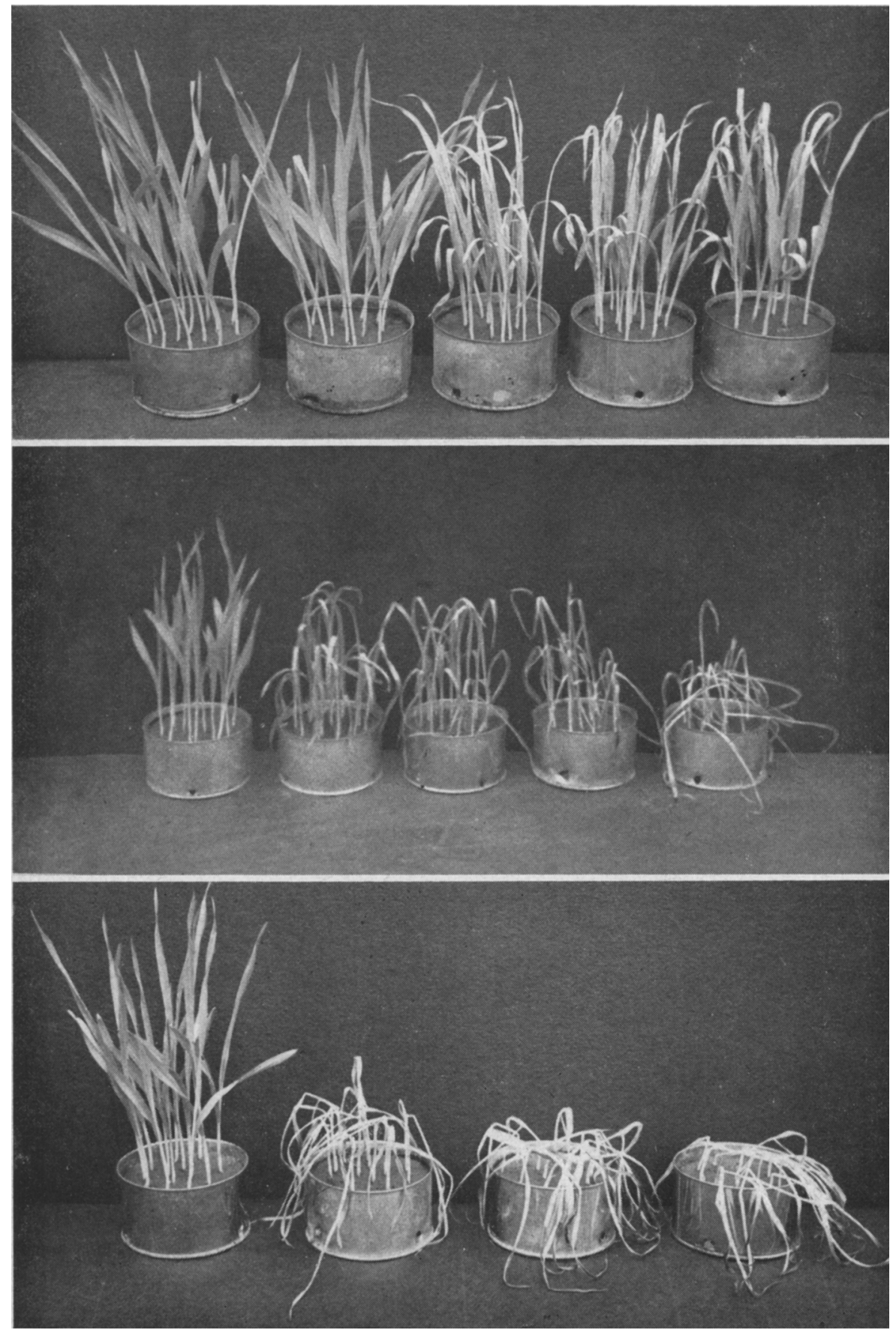

Fig. 6. Effect of different concentrations of toluene vapor on barley. Top, control, plus $0.69 \times 10^{-4} \mathrm{M}$ per liter of air at $1 / 4 \mathrm{hr}$., $1 / 2 \mathrm{hr} ., 1 \mathrm{hr}$., 2 hrs. Center, control, plus $1.3 \times 10^{-4} \mathrm{M}$ at $1 / 4 \mathrm{hr}$., $1 / 2 \mathrm{hr}$., $1 \mathrm{hr}$., 2 hrs. Bottom, control, plus $4.9 \times 10^{-4} \mathrm{M}$ at $1 / 8 \mathrm{hr}$., $1 / 4 \mathrm{hr}$., $1 / 2 \mathrm{hr}$. Photo 24 hours later. 
TABLE 1. RESULTS OF VAPOR TREATMENTS. PER CENT INJURY IN THREE PLANT SPECIES AS AFFECTED BY TIME OF TREATMENT, KIND AND CONCENTRATION OF HYDROCARBON VAPOR.

\begin{tabular}{|c|c|c|c|c|c|c|c|c|c|c|c|c|c|c|c|c|}
\hline \multirow{2}{*}{$\begin{array}{l}\text { Time after } \\
\text { treatment }\end{array}$} & \multicolumn{4}{|c|}{$\begin{array}{c}\text { Benzene } \\
\text { (Concentration } \\
\left.3.2 \times 10^{-4} \mathrm{M}\right)\end{array}$} & \multicolumn{4}{|c|}{$\begin{array}{c}\text { Toluene } \\
(\text { Concentration } \\
\left.1.3 \times 10^{-4} \mathrm{M}\right)\end{array}$} & \multicolumn{4}{|c|}{$\begin{array}{c}\text { Xylene } \\
(\text { Concentration } \\
\left.0.46 \times 10^{-4} \mathrm{M}\right)\end{array}$} & \multicolumn{4}{|c|}{$\begin{array}{c}\text { TMB } \\
\text { (Concentration } \\
\left.0.12 \times 10^{-4} \mathrm{M}\right)\end{array}$} \\
\hline & \multicolumn{4}{|c|}{ Hours treated } & \multicolumn{4}{|c|}{ Hours treated } & \multicolumn{4}{|c|}{ Hours treated } & \multicolumn{4}{|c|}{ Hours treated } \\
\hline & \multicolumn{16}{|c|}{ Barley } \\
\hline 24 hours. & 60 & 85 & 98 & 98 & 70 & 80 & 98 & 100 & 75 & 85 & 95 & 98 & 0 & 10 & 30 & 50 \\
\hline 1 week. & 60 & 85 & 98 & 100 & 50 & 75 & 98 & 100 & 60 & 60 & 75 & 90 & 0 & 30 & 40 & 50 \\
\hline 2 weeks. & 50 & 75 & 98 & 100 & 50 & 60 & 98 & 100 & 25 & 40 & 70 & 85 & 0 & 25 & 30 & 50 \\
\hline \multirow[t]{2}{*}{4 weeks..... } & 30 & 50 & 100 & 100 & 60 & 50 & 98 & 100 & 25 & 25 & 50 & 75 & 0 & 0 & 10 & 25 \\
\hline & \multicolumn{16}{|c|}{ Tomato } \\
\hline 24 hours. & 80 & 90 & 95 & 100 & 85 & 95 & 98 & 100 & 25 & 50 & 85 & 95 & 10 & 25 & 50 & 75 \\
\hline 1 week. & 75 & 90 & 98 & 100 & 75 & 85 & 90 & 100 & 40 & 50 & 85 & 95 & 2 & 30 & 60 & 75 \\
\hline 2 weeks. & 60 & 80 & 95 & 100 & 60 & 75 & 85 & 100 & 50 & 65 & 75 & 90 & 0 & 25 & 40 & 50 \\
\hline \multirow[t]{2}{*}{4 weeks..... } & 40 & 60 & 90 & 100 & 50 & 60 & 75 & 100 & 30 & 30 & 50 & 80 & .. & .. & . & . \\
\hline & \multicolumn{16}{|c|}{ Carrot } \\
\hline 24 hours. & 0 & 85 & 90 & 95 & 0 & 2 & 90 & 98 & 0 & 0 & 2 & 25 & 0 & 0 & 0 & 0 \\
\hline 1 week.. & 0 & 75 & 85 & 95 & 0 & 50 & 85 & 95 & 0 & 0 & 0 & 25 & 0 & 0 & 0 & 0 \\
\hline 2 weeks.. & 0 & 75 & 85 & 95 & 0 & 60 & 75 & 90 & 0 & 0 & 0 & 10 & 0 & 0 & 0 & 0 \\
\hline 4 weeks. . & 0 & 50 & 80 & 90 & 0 & 50 & 75 & 75 & 0 & 0 & 0 & 10 & 0 & 0 & 0 & 0 \\
\hline
\end{tabular}

spray treatments. Where the injury was judged less than 10 per cent (24 hours after application) the weight was greater than 90 per cent of the control weight. Where vapor injury was absent or slight, i.e., 0 to $10 \%$, there was some apparent stimulation since weights exceeded those of controls in over half the samples. Much of this is accountable to carrots, where eight out of 10 cultures showed this response. There was no such indication in the spray lata, probably because the lowest amounts used $(2 \mathrm{ml})$ were still in excess of stimulating quantities.

\section{DISCUSSION: MECHANISM OF TOXIC ACTION}

The means by which a chemical kills a plant may be essentially biophysical or essentially biochemical. The point of view defended here is that physical factors are in themselves sufficient to account for the toxicity of the hydrocarbons in question.

A considerable amount of work has been reported on the effect of petroleum oils on plants (for recent bibliographies see Crafts and Reiber, 1948 ; Minshall and Helson, 1949; Norman, Minarik, and Weintraub, 1950). There is agreement that oils are absorbed by leaves, the rate depending largely on surface tension and viscosity. Entry is both through the cuticle and through stomata, 
TABLE 2. PER CENT INJURY PRODUCED IN BARLEY BY VAPOR OF FOUR HYDROCARBONS, WITH CONCENTRATIONS FIRST LOWER THAN, THEN HIGHER THAN THOSE GIVEN IN TABLE 1.

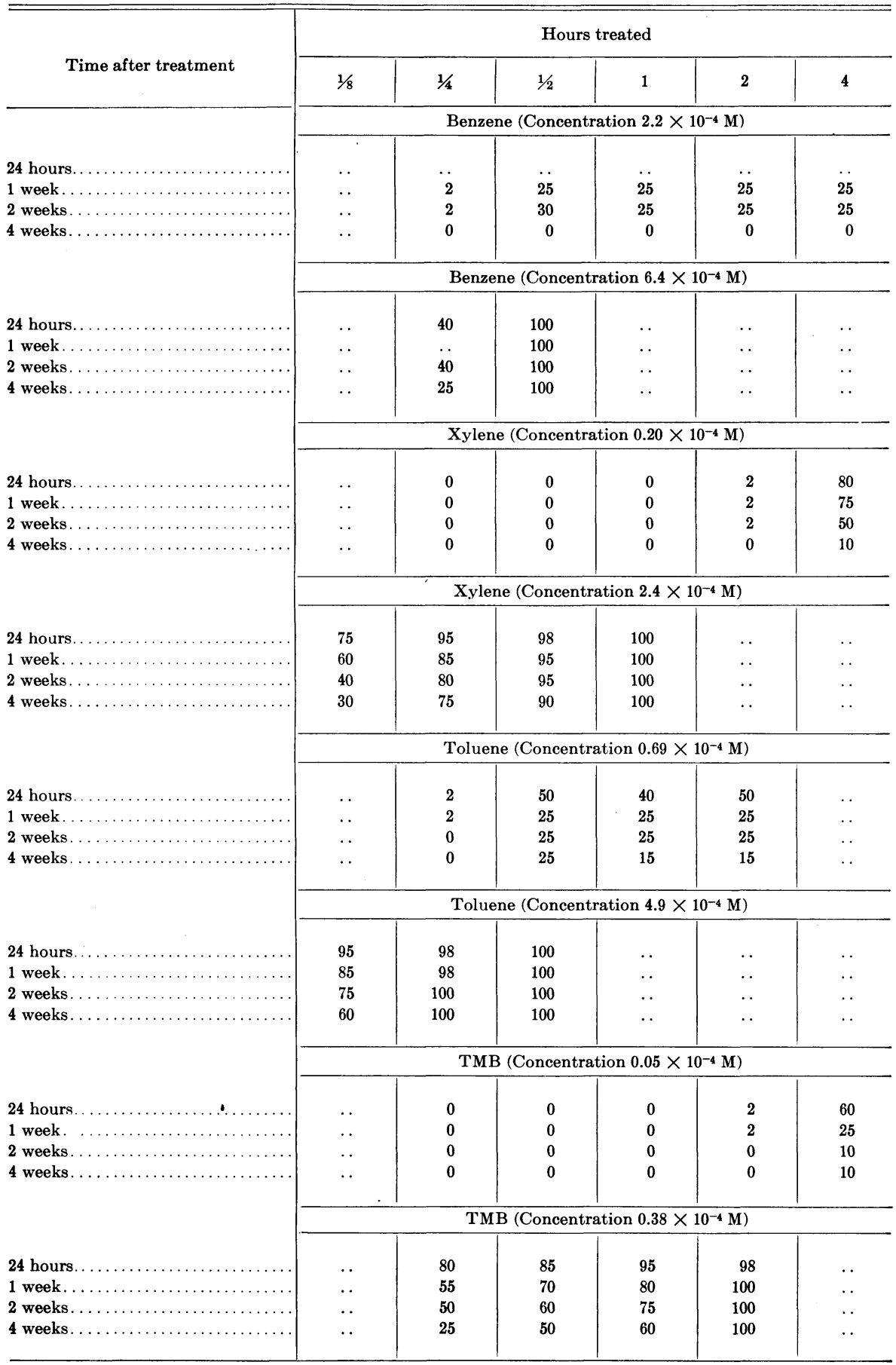


TABLE 3. PER CENT INJURY PRODUCED IN THE THREE PLANT SPECIES BY SPRAYING WITH THE FOUR HYDROCARBONS AS DESCRIBED IN THE TEXT.

\begin{tabular}{|c|c|c|c|c|c|c|c|c|c|c|c|c|c|c|c|c|}
\hline & \multicolumn{4}{|c|}{ Benzene } & \multicolumn{4}{|c|}{ Toluene } & \multicolumn{4}{|c|}{ Xylene } & \multicolumn{4}{|c|}{ TMB } \\
\hline & $2 \mathrm{ml}$ & $5 \mathrm{ml}$ & $10 \mathrm{ml}$ & $20 \mathrm{ml}$ & $2 \mathrm{ml}$ & $5 \mathrm{ml}$ & $10 \mathrm{ml}$ & $20 \mathrm{ml}$ & $2 \mathrm{ml}$ & $5 \mathrm{ml}$ & $10 \mathrm{ml}$ & $20 \mathrm{ml}$ & $2 \mathrm{ml}$ & $5 \mathrm{ml}$ & $10 \mathrm{ml}$ & $20 \mathrm{ml}$ \\
\hline & \multicolumn{16}{|c|}{ Barley } \\
\hline 24 hours. & 25 & 50 & 40 & 80 & 15 & 50 & 60 & 100 & 60 & 75 & 98 & 100 & 80 & 90 & 95 & 98 \\
\hline 1 week. & 25 & 60 & 40 & 80 & 25 & 75 & 75 & 100 & 50 & 85 & 98 & 100 & 75 & 100 & 100 & 100 \\
\hline 2 weeks. . & 5 & 25 & 25 & 70 & 40 & 60 & 60 & 100 & 40 & 85 & 98 & 100 & 60 & 100 & 100 & 100 \\
\hline \multirow[t]{2}{*}{4 weeks...... } & 0 & 5 & 5 & 70 & 50 & 50 & 50 & 100 & 75 & 80 & 95 & 100 & 50 & 100 & 100 & 100 \\
\hline & \multicolumn{16}{|c|}{ Tomato } \\
\hline 24 hours. & 50 & 85 & 90 & 95 & 50 & 75 & 95 & 98 & 90 & 95 & 98 & 98 & 95 & 98 & 98 & 98 \\
\hline 1 week. . & 50 & 85 & 95 & 95 & 50 & 90 & '98 & 100 & 90 & 98 & 100 & 100 & 98 & 100 & 100 & 100 \\
\hline 2 weeks. . & 50 & 90 & 98 & 100 & 60 & 100 & 100 & 100 & 98 & 100 & 100 & 100 & 100 & 100 & 100 & 100 \\
\hline \multirow[t]{2}{*}{4 weeks..... } & 25 & 85 & 98 & 100 & 25 & 100 & 100 & 100 & 98 & 100 & 100 & 100 & 100 & 100 & 100 & 100 \\
\hline & \multicolumn{16}{|c|}{ Carrot } \\
\hline 24 hours... & 25 & 40 & 80 & 95 & 10 & 75 & 98 & 98 & 50 & 95 & 95 & 98 & 85 & 98 & 98 & 98 \\
\hline 1 week....... & 25 & 25 & 75 & 95 & 50 & 85 & 100 & 100 & 75 & 98 & 100 & 100 & 95 & 100 & 100 & 100 \\
\hline 2 weeks. & 10 & 15 & 50 & 95 & 50 & 85 & 100 & 100 & 85 & 100 & 100 & 100 & 95 & 100 & 100 & 100 \\
\hline 4 weeks. . & 20 & 15 & 40 & 90 & 25 & 75 & 98 & 100 & 80 & 100 & 100 & 100 & 98 & 100 & 100 & 100 \\
\hline
\end{tabular}

and the oil moves into the intercellular spaces, replacing some of the air. Rohrbaugh (1934) could detect no spray oil within citrus leaf or stem cells, this in contradiction to the results of Knight et al. (1929) and Young (1935b). As Rohrbaugh points out, it is necessary to distinguish clearly between naturally occurring oils and applied petroleum oils, however it does not seem unlikely that some oil constituents would be able to penetrate the cell wall and enter the protoplasm. Whether or not such penetration could be as evident and as extensive as pictured by Young (1935b) in presenting his "oil mass" theory appears to be somewhat in question. Havis (1950) repeated the stained oil techniques and reported that the red dye was found inside some cells, but emphasized that this was true only where injury was evident. Presence of the dye within cells does not necessarily mean that it moved in with the oil. Contrariwise, absence of intercellular dye is no proof that oil did not enter.

Once in the intercellular spaces, the oil moves by surface activity, facilitated by the lipophilic cell wall surfaces (emphasized by Scott, 1950) exposed to intercellular air. Movement for only short distances was detected in citrus leaves (Rohrbaugh, 1934); it seems quite well established, however, that in many kinds of plants the oil may move from organ to organ, up or down (Knight et al, 1929; Young, 1935a, $b$; Minshall and Helson, 1949). In dandelions, carrots, and parsnips, kerosene-like oils moved downward when ap- 
plied to the leaves and upward when applied to the cut surface of the root (Minshall and Helson, 1949). "Oily" carrots can result from spraying with oils too late in the season, thus indicating movement from the leaves to the root (Crafts, 1947). The movement has been reported to be within conducting elements of vascular bundles (Knight et al, 1929; Ginsberg, 1931); but other work indicates that all (Rohrbaugh, 1934; Minshall and Helson, 1949) or practically all (Young, 1935a, $b$ ) movement is via the intercellular space system.

Minshall and Helson (1949) studied the responses to petroleum naphtha (boiling range $300-400^{\circ} \mathrm{F}$ ) by several kinds of plants. There was an immediate and complete inhibition of photosynthesis, and respiration was retarded. For parsnip this retardation was only temporary, but for mustard the rate decreased to zero and the plants did not recover. Treatment with oils of relatively high toxicity is said to produce an initial marked increase in respiratory rate (Kelley, 1930; Knight et al, 1929). Another response to spraying is a sudden drop in the transpiration rate (Kelley, 1930; Knight et al, 1929; Minshall and Helson, 1949).

The three physiological responses mentioned must of course be partly the result of physical interference with gas interchange. Interpretation would be aided if the measurements could be repeated using a very inert oil, such as paraffin oil.

\section{Type of Toxicity}

Two types of toxicity are known to result from the use of oils on plants: acute and chronic (deOng, Knight, and Chamberlain, 1927; Crafts and Reiber, 1948). Acute toxicity is characterized by a rapid burning of leaves and stems; injury is evident immediately or within 24 hours, and the plant dies within 48 hours. Chronic toxicity is evidenced by slow development of injury-long-lasting effects including yellowing of leaves, stunting, and eventual death.

In agreement with Crafts and Reiber (1948), and Havis (1950), the injury responses observed in these experiments were all of the acute type; no chronic symptoms were evident. The chemicals are strict contact poisons, quickly killing the tissues with which they come in contact. They are not accumulated, and, under some conditions at least, are not translocated. Portions of attached bean leaves immersed in benzene-saturated water were quickly killed; the unimmersed top portions of the leaves were unaffected, even after several days. Carrots will resprout after complete death of the aerial parts, and to some extent barley as well.

In addition to their inhibiting action, the hydrocarbons can stimulate growth when present in small amounts. This was indicated in some of the vapor treatments above. There are some additional observations. Tomato cuttings were placed so that their bases dipped into Hoagland's solution with $0,1 / 100$ saturated, $1 / 10$ saturated, and saturated amounts of hydrocarbon. The solutions were renewed daily for ten days. These tests indicated that $1 / 10$ and $1 / 100$ saturated concentrations produced earlier and more vigorous rooting. Saturated solutions inhibited root formation, and for benzene and toluene the portion of the stem in the solution soon was killed and became 
shrunken. The striking fact is that up to ten days these and all other cuttings showed practically no injury in the leaves. The wick-like basal portions of stems apparently were efficient in permitting sufficient water to be drawn up to maintain an adequate water balance. Subsequent testing with $1 / 5$ and $1 / 2$ saturated solutions resulted in later and more inhibited rooting as compared with the controls. Meites (1939) found stimulation in lupine plants grown in water containing small amounts of benzene. This he interprets as a breakdown of protein, with the release of tryptophane, which is converted to indoleacetic acid, and it is this which is said to cause the increased growth response.

\section{Time and Concentration}

Crafts and Reiber (1948) have pointed out that oil toxicity to plants appears to involve threshold values, where not only dosage but also time must be considered. The results of the gas-chamber tests have a bearing on this problem. At a relatively low concentration the plants are temporarily (reversibly) injured, but the injury does not increase with time, at least up to four hours. As an example, benzene at $2.2 \times 10^{-4} \mathrm{M}$ in air produced the same degree of injury (25\%) at 30 minutes, one, two, and four hours (fig. 7, top). After four weeks this injury had disappeared; the plants resembled the controls. On the other hand, it is also necessary to explain the response of barley to xylene at relatively low $\left(0.20 \times 10^{-4} \mathrm{M}\right)$ concentration (fig. 7 , bottom). The TMB treatment gave the same result. This delay in the appearance of injury may be due to a longer time to reach equilibrium between cell protoplasts and the air. Larger molecules, lower water solubility, lower molar concentration, would be factors in movement. Benzene would reach an equilibrium more rapidly, but since cell lipids probably can absorb a greater amount of xylene, when this equilibrium is reached, more injury is the result.

It is evident that a simple time concentration relationship is not indicated by these experiments. Future experiments should include the effect of low concentrations of hydrocarbon vapor, where the exposure time is much longer than in the tests reported here.

\section{Kind of Diluent, Partition Coefficients, and Activity}

$A$ comparison of the toxicity of benzene and the other substances when they are diluted by air, by water, and by paraffin oil, shows that there is a marked loss of activity in the same order. A killing concentration of benzene in air has been shown to be about $0.0003 \mathrm{M}$; in water it is about $0.01 \mathrm{M}$ or 30 times that in air. Barley shoots inverted for two hours in Hoagland's solution half saturated with benzene showed $75 \%$ injury immediately thereafter, decreasing to $25 \%$ in two weeks. In paraffin oil the killing concentration is in the order of $1 \mathrm{M}$, or 3,000 times that in air. Some tissues, such as carrot leaf epidermis, have been found to remain alive and to show protoplasmic streaming for 24 hours in molar benzene in oil. Root hairs (barley), which are so sensitive to some kinds of herbicides, such as ammonium pentachlorophenate (Currier, 1949) are able to live, though injured, in molar benzene oil for 24 hours. These facts emphasize the importance which must be attached to the diluent-its effect on the activity of the herbicide. 

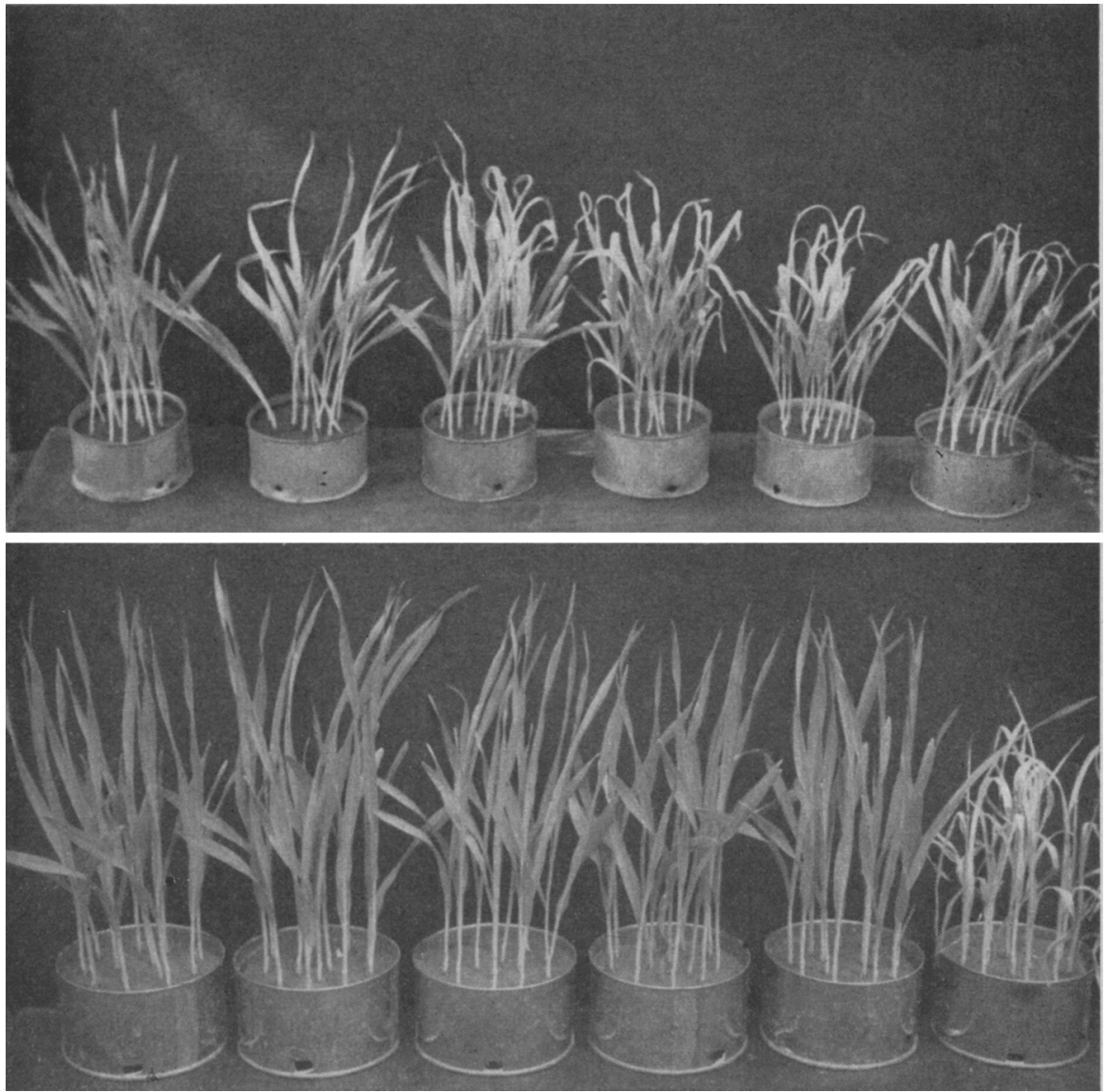

Fig. 7. Top, barley exposed to $2.2 \times 10^{-4} \mathrm{M}$ benzene per liter of air, at $0 \mathrm{hr}$., $1 / 4 \mathrm{hr}$., $1 / 2 \mathrm{hr}$., $1 \mathrm{hr}$., $2 \mathrm{hrs.}, 4 \mathrm{hrs}$. From left to right per eent injury was estimated at $0,2,25,25,25,25$. Photo 24 hours later. After 4 weeks the injured plants had completely recovered. Bottom, barley treated with $0.20 \times 10^{-4} \mathrm{M}$ xylene in air, at $0 \mathrm{hr}$., $1 / 4 \mathrm{hr}$., $1 / 2 \mathrm{hr} ., 1 \mathrm{hr} ., 2 \mathrm{hrs}$., $4 \mathrm{hrs}$. Photo 24 hours later, at which time per cent injury was estimated as $0,0,0,0,2,75$.

The explanation of the loss of activity of benzene in paraffin oil lies in the low partition coefficient $\mathrm{k}=\frac{\text { conc. in water }}{\text { conc. in oil }}=0.0047$. This is the result when $5 \mathrm{ml}$ of paraffin oil which is $\mathrm{M} / 1$ in benzene is brought in contact with $25 \mathrm{ml}$ of water and permitted to come to equilibrium.

If a tissue section is immersed in oil containing $\mathrm{M} / 1$ benzene, the aqueous phase of the cell walls on this basis would be about $0.005 \mathrm{M}$ in benzene, which is less than the $0.01 \mathrm{M}$ aqueous solution designated as killing.

The most definite gross reaction displayed by treated plants is an early and marked increase in permeability as evidenced by characteristic odors of the plant, leakage of cell contents into intercellular spaces, and loss of turgor. This suggests that the lipoid components of the outer cytoplasmic 
membrane (ectoplast) have absorbed the hydrocarbon, or have been partially dissolved out. Plasma membranes are considered to consist of a lipid-protein complex relatively richer in fatty materials than bulk cytoplasm. Assuming that membrane disorganization is the principle effect, it is of interest to consider the water solubility and the water-oil distribution of the hydrocarbons as molecular weight increases. From table 4 it is apparent that an inverse correlation between toxicity of benzene, toluene, and $\mathrm{m}$-xylene and these two physical constants exists, and for mesitylene at least the water solubility is in line.

TABLE 4. SOLUBILITY IN WATER* AND DISTRIBUTION COEFFICIENTS† BETWEEN WATER AND PARAFFIN OIL AT $25^{\circ} \mathrm{C}$ OF FOUR AROMATIC HYDROCARBONS.

\begin{tabular}{|c|c|c|c|}
\hline & \multirow{2}{*}{$\begin{array}{l}\text { Molecular } \\
\text { weight }\end{array}$} & \multirow{2}{*}{$\begin{array}{l}\text { Solubility } \\
\text { in water }\end{array}$} & \multirow{2}{*}{$\begin{array}{c}\text { conc. in water } \\
\text { conc. in oil }\end{array}$} \\
\hline . & & & \\
\hline 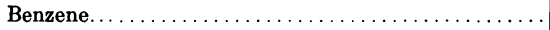 & 78.11 & $0.0222 \mathrm{M}$ & 0.0047 \\
\hline Toluene...... & 92.13 & $0.0058 \mathrm{M}$ & 0.00143 \\
\hline m-Xylene. & 106.16 & $0.00163 \mathrm{M}$ & 0.000358 \\
\hline
\end{tabular}

* Solubilities from Andrews and Keefer (1949). The mesitylene value appears in Seidell (1941).

$\dagger$ Distribution coefficients determined by Dr. L. J. Andrews.

In the gas-chamber experiments hydrocarbon vapor is absorbed by the cuticle of the leaf, which, being lipoid in nature and relatively non-polar, would be expected to take up a considerable amount of it. Vapors also enter through stomata, moving through the intercellular spaces to dissolve in the mesophyll cell walls. The portion passing through the cell wall per unit time depends for one thing on the partition of the substance between air and the cell wall. The liquid held by cell walls may be considered to be almost pure water. Since these hydrocarbons are not very water soluble, not a great deal should be found in the walls, except in those that are heavily infiltrated with cutin or suberin. But as the substance is taken up by the protoplast, small amounts keep moving across. The fact that the outer surfaces of these walls exposed to intercellular air are lipophilic in nature, so important in the distribution of liquid oils within the plant, would tend to cause the absorption of somewhat more hydrocarbon than if the surfaces were hydrophilic.

If the concentration is below the toxic level, at equilibrium or a steady state, the fatty substances in the leaf have greater amounts of benzene than the aqueous phases, but there is an insufficient amount in the lipoid phases of the cell to cause disorganization due to the partition coefficients air/cuticle, cuticle/water, and water/ectoplast. A low concentration in the air will be reflected throughout the system. At a steady-state condition involving a nontoxic concentration it is, in the final analysis, the distribution between the benzene in the external air and the ectoplast that determines whether the plant survives or is killed. That is, the air and the lipids compete for the benzene, with water an intermediate competitor. In addition to the plasma membranes, chloroplasts are rich in lipids (Granick, 1949). Once within the cell, materials such as benzene would become concentrated there, as well as in 
mitochondria, and to a lesser extent in bulk cytoplasm. Thus there would be a multiple partition effect much the same as that postulated by Irwin (1927). As the concentration of benzene in the air increased, the amount absorbed by the ectoplast would be greater, and injury would result. It is possible that at toxic concentrations the cell wall water becomes saturated, movement across the wall would be unimpeded, and the ectoplast would continue to accumulate the solvent.

When plants are sprayed, evaporation from the surface begins immediately, and the amount eventually getting into the leaf is limited by the volatility of the solvent and by the resistance to penetration offered by the leaf. Thus the time factor has a somewhat different meaning here than in the vapor treatments.

Although the concept of partition between phases has been used considerably in studies involving permeability, insecticides, and narcosis, it has not been applied to herbicidal mechanisms to a great degree. Young (1935b) considered oil-miscible plasma membranes of plant cells to be important in herbicidal mechanisms of oils, and this view formed the basis of his so-called oil-mass theory of penetration. Partition phenomena were stated to account for the accumulation of toxicant in the lipid phases of the cell. This is very similar to the view expressed in this paper, but it differs in postulating continuous chains of oil between the intercellular spaces and the interior cytoplasm, when such continuity across the hydrated cell wall would seem to be maintained with difficulty.

The relationship of physical properties to toxicity is discussed by Martin (1928, p. 230-37), who points out the importance of oil-water mechanisms. Ferguson (1939) emphasized that toxic actions can be grouped into two main classes, physical and chemical, and where the mechanism is physical, the activities, but not necessarily concentrations, lie within a narrow range. Regardless of diluent, and regardless of cellular phase, the activity at "equilibrium" is the same in all, and it is this activity which should be measured, not concentration. This important viewpoint is expanded further by Hurst (1943), Burtt (1945), and Webb (1949).

The nareotic action of benzene has been explained in several ways. Originally proposed by Overton and by Meyer (cf. Overton, 1901) the lipid solubility theory has been supported by much evidence. On this basis activity is considered proportional to lipid solubility, or to the lipid-water distribution coefficient. The mechanism may involve both accumulation at cellular surfaces (Traube, 1904) and solvent action (Gavaudan et al, 1946; Tammelin and Löfgren, 1948). Striking parallels are demonstrated by Ferguson (1939) between the toxicity of the normal primary alcohols and physical properties. The latter include solubility, capacity to reduce the surface tension of water, vapor pressure, and partition coefficient between water and cottonseed oil. Gavaudan, Dode, and Poussel (1946) stress the action of indifferent narcotics in breaking lipoprotein bonds in the cytoplasm. According to some workers solubility in water is inversely correlated with anesthetic potency (Cone et al, 1941; Levan and Östergren, 1943). This is known as Richet's (1893) rule and involves a relatively simple determination. Distribution coefficients have been determined for many substances, and a lengthy list of values repre- 
senting ether-water distribution has been assembled by Collander (1949). Other lipid models that have been used include olive oil (Overton, 1901), oleic alcohol (Meyer and Hemmi, 1935), paraffin oil $+0.05 \%$ ergosterol (Tammelin and Löfgren, 1948), corn oil (Cone et al., 1941).

From Collander's (1949) data, substances known to be particularly poisonous are characterized by $k$ values greater than one, while those that are innocuous have small values, as the following examples indicate.

\begin{tabular}{|c|c|c|c|}
\hline & \multicolumn{2}{|l|}{ conc. in ether } & conc. in ether \\
\hline & conc. in water & & conc. in water \\
\hline trichloroacetic acid. & $4.2-10$ & glycerine & 0.00066 \\
\hline phenol & 44 & glucose & 0.0000045 \\
\hline o-nitrophenol & 150 & sucrose & 0.0000011 \\
\hline picric acid . & 3.7 & urea & 0.00047 \\
\hline salicylic acid & 127 & a-alanine & 0.0000014 \\
\hline
\end{tabular}

While plasma membranes might not resemble ether too closely, the general order might be considered to be the same.

In the methyl benzene series, toxicity seems to be inversely correlated with water solubility. Although solubilities of tetra and pentamethyl compounds are not available, it is likely that they decrease with increasing number of methyl groups. Gavaudan (1942) showed increasing toxicity in the series 1,2,4-trimethylbenzene, 1,2,4,5-tetramethylbenzene, pentamethylbenzene. The herbicidal effectiveness of the benzene hydrocarbons has been found to increase with increased substitution of methyl, ethyl, and isopropyl groups. (Crafts and Reiber, 1948; Leonard and Harris, 1950). Toxicity also increased as the side chain was lengthened in the series benzene, toluene, ethylbenzene, n-propylbenzene. Solubilities of these compounds in water decrease in the same order (Seidell, 1941; Andrews and Keefer, 1949). The results of Havis (1950) indicate that the toxicity of the aromatic hydrocarbons tested by him was positively correlated with boiling point up to about $450-500^{\circ} \mathrm{F}$, where toxicity began to decrease. This decrease probably is related to $a$ ) larger molecules and greater difficulty in penetrating the cell wall and ectoplast, $b$ ) a slower diffusion rate, and $c$ ) a lower solubility in water. These factors would tend to decrease the amount of hydrocarbon reaching the protoplast per unit time. It would seem that in the high boiling range the correlation between high toxicity and low water solubility breaks down.

Addition of a carboxyl group increases both oil solubility and potency, but esterification of the carboxyl restores these properties (Gavaudan, Gavaudan and Poussel, 1943). The substances referred to are benzene, benzoic acid, and methyl-(or ethyl, propyl, butyl) benzoate.

Some attention has been given to the effect of benzene on plant cell cytoplasm. In garlic root meristems Meites (1943) found more vacuoles, more spherical vacuolar shape, increased fluidity, granular cytoplasm, and "delipidation," which he attributes to a loosening of protein-lipid bonds. Wada (1939), working with Tradescantia hair cells, photographically describes cytoplasmic disintegration (Entmischung) produced by treatment with benzene and xylene (and other) vapors. Benzene in below-saturated aqueous 
solution produces mitotic disturbances (Gavaudan and Gavaudan, 1943; Östergren and Levan, 1943; Wada, 1939). Naphthalene hydrocarbons behave similarly.

It is interesting that root hairs are quite resistant to these hydrocarbons. Molar benzene in paraffin oil was lethal to red beet-root sections within 24 hours, whereas barley root hairs, though injured, were still alive. In comparison, just the opposite relationship holds with pentachlorophenol in paraffin oil, where $0.0001 \mathrm{M}$ quantities killed root hairs but $0.01 \mathrm{M}$ was required to kill the beet cells. (Currier, 1949).

Certain results reported by Havis (1950) are in accord with the physical explanation of toxicity. The effectiveness of various kinds of hydrocarbons seemed to be related more to boiling point than to chemical structure. Below $280^{\circ} \mathrm{F}$ and above $510^{\circ} \mathrm{F}$ there was little toxicity regardless of whether the substance was an aromatic, cycloparaffin, olefin, or paraffin. To volatility is attributed failure of low boiling compounds to be particularly injurious under outdoor conditions. Toxicity was a direct function of concentration, and the range was very narrow. In selective concentrations, volume of spray had little importance. It was concluded that toxicity is related to penetration into cells, which must involve an effect on the plasma membrane.

\section{Summary of Physical Basis}

The benzenes are toxic because they are good fat solvents. The rapidity of penetration, the sudden increase of permeability, and quick killing can be explained on this basis. The critical point of attack is probably the lipidrich plasma membrane, but other cell lipids might also be involved. Correlation of toxicity with water solubility, water-oil partition coefficients, and boiling points, generally supports the idea to the extent that such physical constants are known. The narrow concentration range, the change in activity with different diluents, and other observations reported are also explicable on a physical basis.

\section{Acute vs. Chronic Toxicity}

The difference in mechanism between the two toxicity types may be a matter of degree rather than kind. Chronic symptoms would develop due to a threshold concentration of toxicant at the protoplast surface. This low concentration would be maintained by virtue of restricted passage across the hydrated cell wall. The important factors here are low solubility in water and large molecules. That chronic injury is not a property of any particular chemical structure was concluded by Havis (1950), where of 31 compounds tested only five produced chronic injury, and these possessed boiling points of $482,536,548,550-558$, and $554-572^{\circ} \mathrm{F}$. The five substances included three of the four different classes of hydrocarbons tested. Similarly, acute injury was characteristic of all classes.

\section{Biochemical Considerations}

The biochemical explanation of acute oil toxicity is opposed by the following.

a) The responses by the three plant species to any of the benzene com- 
pounds were qualitatively the same. Similarly, there was only a qualitative difference in the response of any one species to all of the four benzenes.

b) Although benzene, toluene, xylene, mesitylene and other hydrocarbons are known to be metabolized by bacteria (Zobell, 1946), and by animals (Williams, 1947), there are no reported detoxification mechanisms for these substances in higher plants. This of course may be due to the fact that such mechanisms have not been sought to any degree. Benzene is reported (Williams, 1947) to be oxidized to phenol in the animal body, with phenylmercapturic acid as a minor metabolite. Subsequently phenol is believed to be oxidized to muconic acid through several intermediates : phenylglucuronide, phenylsulfuric acid, catechol and quinol and their conjugates. Toluene is oxidized by animals mainly to benzoic acid and excreted as hippuric acid. M-xylene is oxidized to m-toluric acid. Mesitylene metabolism results in the formation of mesitylenic acid.

c) In spite of the above, the hydrocarbons are not particularly active chemically, and their effects are produced so rapidly in plants that enzymatic activity would probably be too slow. An important consideration is that the saturated straight chain hydrocarbons are especially unreactive, yet can be quite toxic (Leonard and Harris, 1950). Introduction of a double bond into straight chain paraffin molecules increased the toxicity only very slightly according to Havis (1950). However, a contrary result was obtained by Leonard and Harris (1950), working with cotton hypocotyls. N-heptane produced no visible injury to seven-day-old hypocotyls, while heptene-2 produced very rapid discoloration, which became olive colored and then brown as the tissues died. Similar differences were observed between n-octane and octene; also between n-decane and decene-1. Similar but less striking differences were noted between $n$-dodocane and dodecene- 1 and n-tetradecane and tetradecene-1. These data can readily be explained on the basis of greater solubility of the unsaturated straight-chain hydrocarbons in the cell membranes than the similar saturated hydrocarbons; however, these compounds are readily oxidized and chemical effects cannot be excluded with the olefins. It was interesting to note that with respect to nutgrass shoots these differences between the saturated and unsaturated hydrocarbons were much less marked than with cotton hypocotyls.

d) Minshall and Helson (1949) suggested that inhibition of photosynthesis is involved in the mechanism of oil toxicity. This is probably correct, but it is difficult to agree that cessation of transpiration is the immediate cause of such inhibition. How stoppage of transpiration can result in a reduced water supply, and also how this would have a significant bearing on photosynthesis is not entirely clear. Havis (1949) points out that since nontoxic oils spread through tissues as rapidly as toxic oils they would presumably have a similar effect in blocking water movement.

Johnson (1948) found that highly refined oils, free of peroxides and acids, had no effect on the respiratory rate of bean leaf tissue. However when the oils were partially oxidized, acids and peroxides formed which inhibited respiration and caused injury. Inhibition was due more to acidity than to peroxides. These results suggested that interference with the energy relations of the cells may produce many of the symptoms of chronic oil injury. This 
work is in line with that of Tucker (1936) who concluded that toxicity of fairly heavy oils is due to the formation of asphaltic acids. Further study is necessary to determine to what extent higher plants can oxidize hydrocarbons. In our view they are probably not to be considered important factors in the acute type of oil injury. Aromatics stored for a year in the light in glass containers showed no increase in toxicity (Havis, 1950).

\section{DISCUSSION: BASIS OF SELECTIVITY}

Members of the family Umbelliferae-including carrot, parsnip, celery, dill, wild licorice, parsley-display a resistance to both petroleum weed oils and pure aromatic hydrocarbons. This does not imply any great immunity, but only that these plants possess a margin of safety which permits, for example, field control of carrot weeds with little or no damage to the crop (Crafts, 1947). It has been emphasized that herbicidal selectivity is only relative (Crafts, 1946) and resistance of the umbellifers to oils is a good example.

Opposed to a biochemical explanation as the cause of this resistance is the observation, stated earlier, that carrots seem to respond to oils and to pure hydrocarbons in the same general way that more susceptible plants do, except that they can withstand higher concentrations.

Selectivity on the basis of gross morphological differences provides no explanation of carrot resistance, for the following reasons. a) Some plants by reason of narrow and smooth leaves are able to shed sprays to a greater extent than others. This cannot be a factor here because the hydrocarbons readily adhere to, spread over, and enter the leaves. $b$ ) Even though carrot leaves are finely divided, the amount reaching the individual cell is the same as for plants with broad leaves ; furthermore, leaf shape varies considerably within the family, e.g., parsnip vs. carrot. c) Measurements show that there is no significant difference in cell size among leaves of barley, tomato, and carrot, which precludes the suggestion that smaller cells might be more resistant. d) Possession by the carrot family of oil ducts, which would act as protective "sinks" for the benzenes, would not seem to be important in selectivity, since their volume is so small compared to the total tissue of the leaf. This matter was considered by Havis (1950) in his study of oil selectivity. Among plants treated were ten species possessing oil ducts and glands. While there was some suggestion that these plants were somewhat more tolerant than those not possessing ducts and glands, no definite conclusions could be drawn. Carrot and three conifer species showed high resistance; others moderate to none. Where leaves are literally soaked in oil or pure hydrocarbon, it seems doubtful if these oil reservoirs could function rapidly enough and efficiently enough to protect the surrounding tissue. The observation of Havis that the amount of toxicant (diluted in nontoxic oil) sprayed on the leaves was unimportant as long as a selective concentration was employed, supports this view. He also found that carrot leaves could be immersed in Stoddart Solvent without injury. Oil ducts would have to be extremely efficient to protect the leaf under this condition. Finally, the toxicants would have to pass through living cells to reach the ducts, unless they moved entirely via cell walls, in which case movement would be very slow.

On physical bases the selectivity of carrots may be attributed to one or 
both of the following. a) Due to the structure of the cell wall, the amount of benzene moving through to the protoplast per unit time may be less than for other plants. The structural factors could be chemical constituents, degree of hydration, and thickness. Thus it would be the time factor, plus the volatility of the hydrocarbons, that protects carrots. $b$ ) The ectoplast of carrot cells may possess some particular structure which resists injury by oils. This may be related to water-oil distribution, and lower solubility in the oil phase, or to some other structural factor or factors. Although consideration of the evidence described on the foregoing pages seems to favor alternative $b$, additional study is needed, possibly directed at the plasma membranes themselves, for better understanding of the problem.

\section{SUMMARY}

Plants were treated in a gas chamber with vapors of four aromatic hydrocarbons, and results were compared with tests using undiluted liquid spray.

Toxicity increased in the order : benzene, toluene, xylene, trimethylbenzenes in both vapor and spray treatments.

Resistance of plants to both vapor and spray increased in the order: tomato, barley, carrot.

Activity of the hydrocarbon vapor diluted with air, on a molar concentration basis, is roughly 30 times that where water is the diluent, and about 3,000 times that in paraffin oil. Nature of the diluent is important.

Toxicity of the vapor lies within a narrow concentration range. Nontoxic amounts seem to be stimulating.

Mechanism of acute toxicity of these hydrocarbons probably involves disorganization of the outer plasma membrane of the cell, due to solvent action on the lipoid constituents. Partition phenomena determine concentration of hydrocarbon at point of action.

Carrots showed relative resistance in all treatments. Basis of this selectivity may lie in the character of the cell wall or of the outer plasma membrane.

\section{ACKNOWLEDGMENTS}

The writer is indebted to Dr. A. S. Crafts for helpful suggestions and advice, to Dr. O. A. Leonard for critically reading the manuscript, to Dr. L. A. Andrews of the Division of Chemistry for determining certain physical constants, and to H. R. Drever for technical assistance in conducting the greenhouse experiments.

\section{LITERATURE CITED}

ANDREWS, L. J., and R. M. KEEFER.

1949. Cation complexes of compounds containing carbon-carbon double bonds. IV. The argentation of aromatic hydrocarbons. Jour. Amer. Chem. Soc. 71:3644-47.

BurTt, E. T.

1945. The mode of action of sheep dips. Ann. Appl. Biol. 32:247-60.

CollaAnder, $R$.

1949. Die Verteilung organischer Verbindungen zwischen $\overparen{A}$ ther und Wasser. Acta Chem. Scand. 3:717-49.

Cone, N. M., S. E. Forman, and J. C. Krantz.

1941. Relationship between anesthetic potency and physical properties. Soe. Expt. Biol. and Med. Proc. 48:461-63. 
CRAF'TS, A. S.

1946. Selectivity of herbicides. Plant Physiol. 21:345-61.

1947. Oil sprays for weeding carrots and related crops. Calif. Agr. Ext. Cir. 136:1-12. Craft's, A. S., and H. G. ReIBer.

1948. Herbicidal properties of oils. Hilgardia 18:77-156.

CURRIER, H. B.

1949. Responses of plant cells to herbicides. Plant Physiol. 24 :601-09.

DeOng, E. R., H. Knight, and J. C. Chamberlin.

1927. A preliminary study of petroleum oil as an insecticide for citrus trees. Hilgardia $2: 351-84$.

Ferguson, J.

1939. The use of chemical potentials as indices of toxicity. Roy. Soc. London, Proc., Ser. B. $127: 387-404$.

Gavaudan, P.

1942. Action sur la caryocinèse, la cytodiérèse et la croissance végétales des hydrocarbures eycliques à deux noyaux benzéniques sans atomes de carbone communs et des dérivés nitrés et méthylés du benzène, du naphtalène et de l'acénaphtène. Soc. de Biol. [Paris] Compt. Rend. 136:383-84.

Gavaudan, P., and N. Gavaudan.

1943. Action du benzène et de ses homologues sur la caryocinèse et la cytodiérèse régétales. Soc. de Biol. [Paris] Compt. Rend. 137:50.

Gavaudan, P., N. Gavaudan, and H. Poussel.

1943. Activité mito-inhibitrice de la plupart des fonctions dans la série aromatique opposée à l'activité practiquement nulle ou réduite de la fonction carboxyle. Soc. de Biol. [Paris] Compt. Rend. 137:570-71.

Gavaudan, P., M. Dode, and H. Poussel.

1946. Contribution à l'etude du mecanisme de la narcose par les narcotiques indifférents. Rec. des Trav. Toxicol. et Pharmacodyn. Cell. (Trav. Sci. Sta. Essais Bouchet) 2:1-36. Abstract in Biol. Abs. $22: 2696$.

GinsBerg, J. M.

1931. Penetration of petroleum oils into plant tissue. Jour. Agr. Res. 43:469-74.

Granick, S.

1949. The chloroplasts: their structure, composition, and development. In Photosynthesis in Plants (The Iowa State College Press, Ames, Iowa) : 113-32.

Havis, J. R.

1948. The herbicidal properties of certain pure petroleum hydrocarbons (preliminary report). Amer. Soc. Hort. Sci. Proc. 51:545-46.

1950. Herbicidal properties of petroleum hydrocarbons. N.Y. (Cornell) Agr. Expt. Sta. Mem. 298:1-20.

Hurst, H.

1943. Principles of insecticidal action as a guide to drug reactivity-phase relationships. Faraday Soc. Trans. 39:390-411.

IRWIN, MI.

1927. Multiple partition eoefficients of penetration. Soc. Expt. Biol. and Med. Proc. $25: 127-29$.

Johnson, C. M.

1948. The influence of petroleum spray oils and their oxidation products on the metabolism of bean leaves. University of California, Berkeley. (Unpublished doctoral dissertation.)

Kelley, T. W.

1930. Effect of certain hydrocarbon oils on the transpiration rate of some deciduous tree fruits. Ill. Agr. Expt. Sta. Bul. 353:579-600.

Knight, H., J. C. Chamberiain, and C. D. Samuels.

1929. On some limiting factors in the use of saturated petroleum oils as insecticides. Plant Physiol. 4:299-321. 
LEONARD, O. A., and V. C. Harris.

1950. The effect of certain hydrocarbon compounds upon the hypocotyls of cotton and soybeans and upon the shoots of nutgrass and Johnson grass. Southern Weed Conference, Biloxi, Miss., Proc.

Levan, A., and G. Östergren.

1943. The mechanism of c-mitotic action. Observations on the naphthalene series. Hereditas $29: 381-443$.

Martin, H.

1928. The scientific principles of plant protection. 316 p. Edward Arnold and Co., London.

MeITÈs, $\mathrm{M}$.

1939. Propriétés excito-formatrices de l'eau benzinée. Soc. Bot. de France Bul. 86:30410.

1943. Action de l'eau benzinée sur la cellule végétale. Application de la délepidation benzénique a la technique mitochondriale de Regaud. Soc. de Bíol. [Paris] Compt. Rend. 137:225-26.

Meyer, K. H., and H. Hemmi.

1935. Beiträge zur Theorie der Narkose. III. Biochem. Ztschr. 277:39-71.

Minshall, W. H., and V. A. Helson.

1949. The herbicidal action of oils. Amer. Soc. Hort. Sci. Proc. 53:294-98.

Norman, A. G., C. E. Minarik, and R. L. Weintraub.

1950. Herbicides. Ann. Rev. of Plant Physiol. 1:140-68.

Östergren, G., and A. Levan.

1943. The connection between c-mitotic activity and water solubility in some monocyelic compounds. Hereditas 29:496-98.

Overton, E.

1901. Studien über die Narkose. Gustav Fischer, Jena, 1901.

Richet, M. Charles.

1893. Note sur le rapport entre la toxicité et les propriétés physiques des corps. Soc. de Biol. [Paris] Compt. Rend. $45: 775-76$.

Rohrbaugh, P. W.

1934. Penetration and accumulation of petroleum spray oils in the leaves, twigs, and fruit of citrus trees. Plant Physiol. 9:699-730.

ScoTT, F. M.

1950. Internal suberization of tissues. Bot. Gaz. 111:378-94.

SEIDELL, A.

1941. Solubilities of organic compounds. $3 d$ ed. D. Van Nostrand Co., Ine., New York.

TAMMELIN, L. E., and N. LöFGREN.

1948. The action of anesthetics on interfaces. Acta Chem. Scand. 1:871-83.

Traube, J.

1904. Theorie der Osmose und Narkose. Pflügers Arch. f. die Gesam. Physiol. 105: $541-58$.

Tucker, R. P.

1936. Oil sprays. Chemical properties of petroleum oil unsaturates causing injury to foliage. Indus. and Engin. Chem. Analyt. Ed. 28:458-61.

WADA, B.

1939. Experimentelle Untersuchungen lebender Zellen in der Teilung. III. Die Einwirkung der Dämpfe verschiedener Substanzen auf die Mitose bei den TradescantiaHaarzellen. Cytologia 9:460-79.

WEBB, J. E.

1949. The permeability of insect cuticle. Soc. Expt. Biol. and Med. Symposia III:143-63. WILLIAMS, R. T.

1947. Detoxication mechanisms. John Wiley and Sons., New York. 
Young, P. $\Lambda$.

1935a. Distribution and effect of petroleum oils and kerosenes in potato, cucumber, turnip, barley, and onion. Jour. Agr. Res. 51:925-34.

$1935 \mathrm{~b}$. Oil-mass theory of petroleum-oil penetration into protoplasm. Amer. Jour. Bot. 22:1-8.

ZOBELL, C. E.

1946. $\Lambda$ ction of microörganisms on hydrocarbons. Bact. Rev. 10:1-49. 
The journal Hilgardia is published at irregular intervals, in volumes of about 600 pages. The number of issues per volume varies.

Subscriptions are not sold. The periodical is sent as published only to libraries, or to institutions in foreign countries having publications to offer in exchange.

You may obtain a single copy of any issue free, as long as the supply lasts; please request by volume and issue number from:

\section{Publications Office \\ College of Agriculture \\ Berkeley 4, California}

The limit to nonresidents of California is 10 separate issues on a single order. A list of the issues still available will be sent on request. 